\title{
Effect of high dose intravenous ascorbic acid on the level of inflammation in patients with rheumatoid arthritis
}

\author{
N. Mikirova", A. Rogers, J. Casciari, P. Taylor

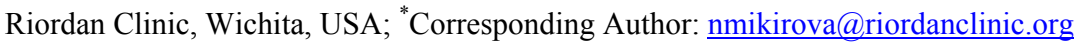 \\ Received 13 September 2012; revised 16 October 2012; accepted 14 November 2012
}

\begin{abstract}
Rheumatoid arthritis (RA) is a major inflammatory joint disease that causes cartilage destruction, bone erosions, and joint destruction. Oxidative stress is elevated in RA patients implying reactive oxygen species (ROS) are possible mediators of tissue damage. ROS trigger a cascade of events through nuclear factors' activation (NF-kappa B), which up-regulates gene expression of pro-inflammatory cytokines that mediate the immune responses causing inflammation. As ascorbic acid can reduce oxidative stress, decrease production of pro-inflammatory cytokines, and suppress the activation of NF-kappa B, we suggest that millimolar concentration of ascorbic acid may be useful in RA treatment. In our study we analyzed the effect of intravenous vitamin C (IVC) treatment on eleven subjects with RA. Our data suggest that IVC therapy with dosages of $7.5 \mathrm{~g}-50 \mathrm{~g}$ can reduce inflammation. The level of inflammation as measured by $\mathrm{C}$-reactive protein levels was decreased on average by $44 \%$. Based on our pilot study, we hypothesize that IVC therapy can be a useful strategy in treating RA.
\end{abstract}

Keywords: Rheumatoid Arthritis; Inflammation; C-Reactive Protein; Intravenous Vitamin C

\section{INTRODUCTION}

Rheumatoid arthritis (RA) is a major inflammatory joint disease involving damage to cartilage, bone and joints. In severe cases, it can also lead to rheumatoid nodules, vasculitis, heart disease, lung disease, anemia, and peripheral neuropathy. There is no cure for RA at present. Treatment usually beings with non-steroidal anti-inflammatory drugs (ASAIDs) or COX-2 inhibitors, with glucocorticoids or "disease modifying drugs" such as gold and methotrexate being employed in more severe cases. These treatments have limited success and may cause significant adverse effects. Alternative and complementary medicine (CAM) approaches to arthritis include supplementation with gamma-linolenic acid, fish oil (and/or omega 3 fatty acids), antioxidants (such as vitamins $\mathrm{C}$, E, quercetin, and lipoic acid), and dietary adjustments [1]. So far, clinical studies testing these CAM therapies have not demonstrated significant benefits to RA patients [2-7].

RA is thought to be an autoimmune illness. Hallmarks of RA pathology include chronic inflammation and synovial hyperplasia. The synovial membrane, a delicate tissue structure one or two cell layers thick that lines joint cavities, undergoes morphological changes including thickening of intimal lining and formation of invasive tumor-like structures called "pannus' with the onset of RA. In RA patients, T-lymphocytes infiltrate the synovial membrane and produce pro-inflammatory cytokines (such as IL-1, IL-6, and TNF- $\alpha$ ) [8], which in turn stimulate release of tissue-destroying matrix metalloproteinases [9], pro-inflammatory enzymes such as Cox-2, and prostaglandins [10-13]. This eventually leads to degeneration of cartilage extracellular matrix. Moreover, oxidative stress and reactive oxygen species (ROS) are elevated in RA patients [14-18], presumably due to the activity of activated macrophages and granulocytes. ROS are known to activate cellular redox sensitive transcription factors, including nuclear factor B (NF- $\kappa \mathrm{B})$, that up regulate genes encoding pro-inflammatory cytokines and enzymes [19-21].

Since NF- $\kappa \mathrm{B}$ is a key transcription factor regulating almost all of the pro-inflammatory factors involved in pathogenesis and progression of rheumatoid arthritis [22, 23], it is a potential target for anti-arthritis therapy. The presence of activated NF- $\kappa \mathrm{B}$ transcription factors has been demonstrated in cultured synovial fibroblasts [24-26], human arthritic joints [27-32] and the joints of animals with experimentally induced RA $[33,34]$. Through its up-regulation of IL- 1 and TNF- $\alpha$, NF- $\kappa$ B has an inhibitory effect on cartilage generation (chondro 
genesis) and interferes with the differentiation of mesenchymal stem cells into chondrocytes [35]. Bone marrow derived precursor cells that would normally differentiate into mesenchymal cell types instead, under conditions of elevated inflammation, form fibroblast-like synoviocytes (FLS) characteristic of the tumor-like pannus [36-38]. In a study using an animal model of RA, NF- $\kappa \mathrm{B}$ was required for the induction of inflammatory cytokines in primary synovial fibroblasts, and suppression of NF$\kappa \mathrm{B}$ enhanced apoptosis in the synovium [39]. Thus, NF$\kappa \mathrm{B}$ activation may contribute to hyperplasia by increasing inflammation and inhibiting apoptosis.

Our clinic has long been interested in the use of ascorbate (vitamin C) at millimolar concentrations (attainable via intravenous infusions) to treat illnesses associated with inflammation, including cancer, atherosclerosis, and viral infections [40-48]. At high doses, ascorbate has been shown to reduce the production of pro-inflammatory cytokines [49-51] and to affect the activation of $\mathrm{NF}-\kappa \mathrm{B}$ [52-55]. The effect of ascorbate on NF- $\kappa \mathrm{B}$ in vitro seems to be concentration dependent: one study indicated that $0.2 \mathrm{mM}$ ascorbate enhanced NF- $\kappa \mathrm{B}$ activation in Jurkat T-cells [53], while two other studies using higher ascorbate concentrations showed inhibition of NF- $\kappa \mathrm{B}$ in endothelial cells [52] and other human cell types [55]. Ascorbate has other properties that suggest it may be useful in treating rheumatoid arthritis: it is an antioxidant that scavenges ROS [56,57]; it supports collagen formation and enhances extracellular matrix protein synthesis $[58,59]$. Interestingly, RA patients tend to be vitamin $\mathrm{C}$ deficient, with high supplementation doses required to maintain plasma ascorbate at acceptable levels [60]. Other studies show below-normal ascorbate concentrations in synovial fluid of RA patients.

As a first step toward investigating the use of intravenous ascorbate to treat rheumatoid arthritis, we examined our patient database to see how intravenous ascorbate therapy has affected the inflammation marker C-reactive protein (CRP) in arthritis patients.

\section{MATERIALS AND METHODS}

We searched our database for rheumatoid arthritis patients who 1) were treated with intravenous ascorbate therapy and 2) had pre-treatment and post-treatment assessment of C-reactive protein. Our search yielded eleven subjects, all females from 45 to 69 years old. Key lab parameters for this group are shown in Table 1.

Blood chemistry parameters were obtained using standard medical lab procedures. CRP levels in blood (serum or heparin-plasma) were analyzed using a particle-enhanced immune-turbidimetric assay (CRP Ultra WR Reagent kit, Genzyme) according to manufacturer's instructions on an automated analyzer (CobasMIRA, Roche Diagnostics). According to the reagent kit manu- facturers, an upper limit on the normal CRP range (within two standard deviation of the average) was 1.9 $\mathrm{mg} / \mathrm{L}$.

Patients were treated by intravenous vitamin $\mathrm{C}$ infusions using our clinic's standard intravenous ascorbate (IVC) therapy protocol [61]. Briefly, patients were first screened for glucose-6-phosphate dehydrogenase deficiency, as this deficiency can cause hemolysis. Patients with G6PDH deficiency were not given IVC. Subjects were then given IVC at doses of $7.5 \mathrm{~g}, 15 \mathrm{~g}$ or 25 grams infused by slow drip in saline solution. To ensure that patient has adequate renal function, hydration and urinary voiding capacity, baseline lab tests were performed that include a serum chemistry profile and urinalysis. In some cases, additional supplements such as vitamin B6, vitamin C, EPA, and evening primrose oil were also given.

\section{RESULTS}

The eleven rheumatoid arthritis patients in our study were characterized by moderate to high levels of the inflammation marker CRP accompanying moderate to severe discomfort levels (Table 1). Based on a previously published classification system for CRP as risk factor [62], two of our subjects had moderate $(1-3 \mathrm{mg} / \mathrm{L})$ inflammation while the other nine subjects had high $(6.7$ $\mathrm{mg} / \mathrm{L}-44 \mathrm{mg} / \mathrm{L}$ ) levels of inflammation. The changes in CRP levels after IVC therapy are shown in Table 2.

The average CRP level before treatment was $9.4 \pm 4.6$ (sd) $\mathrm{mg} / \mathrm{L}$, while the average after IVC therapy was $6.4 \pm$ 4.6 (sd) $\mathrm{mg} / \mathrm{L}$.

Nine of the eleven subjects (the exceptions being subjects 8 and 11) showed a net decrease in inflammation (as indicated by CRP decreases) during IVC treatment. For these nine subjects, the average CRP decrease was $44 \pm 23$ (sd)\%. Figures 1 and 2 show examples of how $\mathrm{CRP}$ changed over time in four subjects who received the IVC treatments. Subject 6 had twenty IVC treatments of 15 grams each over a 130 day period. Her CRP level decreased steadily from $12.6 \mathrm{mg} / \mathrm{L}$ to $1.4 \mathrm{mg} / \mathrm{L}$. Subject 5 had similar results with four treatments over a three month period. Subjects 8 and 11 were unusual in that they showed dramatic increases in CRP at certain points in their treatment, with gradual decreases during the remaining periods.

Examining those subjects who showed a net CRP decrease, there is some hint that the effect may be IVC treatment frequency dependent. This is shown in Figure 3, where the drop in CRP is plotted against the average interval between treatments (the number of days of treatment divided by total amount of given treatments).

This is not definitive, but it suggests that further study is warranted. The limitation of our study is that the IVC 
Table 1. Pre-treatment characteristics of eleven rheumatoid arthritis patients analyzed in the present study are given, including age, sex, serum cholesterol (mg/dL), omega-3 and omega-6 fatty acids, $\Omega 6: \Omega 3$ ratios, weight (lbs), subject rated pain level (1-7), and c-reactive protein (CRP, $\mathrm{mg} / \mathrm{L})$ levels.

\begin{tabular}{rcccccccc}
\hline & Age & Sex & Cholesterol & Omega-6 & Omega-3 & Ratio & Weight & Pain (maximum level 7) \\
\hline subject 1 & 69 & F & 180 & 26.3 & 5.4 & 4.87 & 165 & 5 \\
subject 2 & 56 & F & 190 & 24.93 & 4.18 & 5.96 & 171.2 & 5 \\
subject 3 & 28 & F & 170 & 23.1 & 5.5 & 4.20 & 145.4 & 6 \\
subject 4 & 65 & F & 230 & 320.8 & 47.1 & 6.81 & 197.7 & 5 \\
subject 5 & 49 & F & 195 & 27.12 & 5.07 & 5.35 & 175 & 6 \\
subject 6 & 62 & F & 244 & 27.19 & 5.28 & 5.15 & 155 & 7 \\
subject 7 & 54 & F & 256 & 24.76 & 2.28 & 10.86 & 180 & 7 \\
subject 8 & 53 & F & 210 & 308.2 & 62.6 & 4.92 & 188 & 7 \\
subject 9 & 43 & F & 177 & 25 & 5.2 & 4.81 & 160 & 7 \\
subject 10 & 40 & F & 274 & 342 & 50.3 & 6.80 & 217 & 4 \\
subject 11 & 45 & F & 178 & 370.9 & 52.6 & 7.05 & 230 & 5 \\
\hline
\end{tabular}

Table 2. C-reactive protein (CRP, mg/L) levels before and after IVC therapy. The number of IVC treatments at each dose, along with the total number of days of therapy, is given. Where applicable, use additional supplements used during therapy are indicated.

\begin{tabular}{|c|c|c|c|c|c|c|c|c|}
\hline & $\begin{array}{l}\text { CRP } \\
\text { before }\end{array}$ & $\begin{array}{l}\text { CRP } \\
\text { after }\end{array}$ & $\begin{array}{l}\text { CRP } \\
(\%)\end{array}$ & $\begin{array}{l}\text { IVC } \\
7.5 \mathrm{~g}\end{array}$ & $\begin{array}{l}\text { IVC } \\
15 \mathrm{~g}\end{array}$ & $\begin{array}{l}\text { IVC } \\
25 \mathrm{~g}\end{array}$ & $\begin{array}{l}\text { IVC } \\
\text { days }\end{array}$ & $\begin{array}{l}\text { Additional supplements used } \\
\text { (Oral unless noted) }\end{array}$ \\
\hline subject 1 & 11 & 8.7 & -21 & 1 & 1 & 5 & 100 & EPA, vitamin B6, magnesium \\
\hline subject 2 & 12.3 & 8.5 & -31 & & 1 & & 150 & $1 \mathrm{~g}$ Vitamin C orally, EPA \\
\hline subject 3 & 2.7 & 1.9 & -30 & 2 & & & 132 & B-complex, super EPA \\
\hline subject 4 & 6.8 & 3.9 & -43 & & 1 & 2 & 800 & $1 \mathrm{~g}$ Vitamin C orally, B-vitamins \\
\hline subject 5 & 17.2 & 4.4 & -75 & & 4 & & 96 & EPA, evening primrose oil \\
\hline subject 6 & 12.6 & 1.4 & -89 & & 20 & & 129 & $\begin{array}{c}1 \mathrm{~g} \text { vitamin C orally, EPA, evening primrose oil, } \\
\text { coenzyme Q10 }\end{array}$ \\
\hline subject 7 & 12.1 & 8 & -34 & & & 5 & 177 & $1 \mathrm{~g}$ vitamin $\mathrm{C}$ orally, B-complex, EPA \\
\hline subject 8-a & 11.9 & 44.8 & +277 & & 3 & 8 & 331 & $\begin{array}{c}\text { B6 IVC injections (1mg), EPA, vitamin D, } \\
\text { DHEA }\end{array}$ \\
\hline subject 8-b & 44.8 & 27.1 & -40 & & & 5 & 208 & B6 IVC injections, EPA, vitamin D, DHEA \\
\hline Subject 8-c & 27.1 & 14.8 & -45 & 2 & & 1 & 383 & B6 IVC injections, EPA, vitamin D \\
\hline Subject 8-total & 11.9 & 14.9 & 24 & 2 & 3 & 14 & 922 & \\
\hline subject 9 & 2.09 & 0.99 & -53 & 1 & & & 115 & DHEA, $1 \mathrm{~g}$ vitamin C, vitamins B5, B6, D, EFA \\
\hline subject 10 & 6.7 & 5 & -25 & 2 & & 1 & 206 & $\begin{array}{l}\text { B6 IVC injections, } 500 \mathrm{mg} \text { Vitamin C, EFA, B } \\
\text { plex IV }\end{array}$ \\
\hline subject $11-\mathrm{a}$ & 7.6 & 3.1 & -59 & & 16 & & 187 & B-complex IV, B6 IV infusion, EPA, vitamin D \\
\hline subject $11-b$ & 3.1 & 13.1 & 320 & & 10 & & 99 & B6 IVC, evening primrose oil, EPA \\
\hline subject $11-\mathrm{c}$ & 17.6 & 13.1 & -26 & & 5 & & 55 & B-plex, B6 IVC, evening primrose oil, EPA \\
\hline Subject 11-total & 7.6 & 13.1 & 72 & & 31 & & 341 & \\
\hline
\end{tabular}

administration protocol was different for different patients.

Finally, since CRP levels can be affected by body mass, we examined the subjects' weight change during treatment. In most cases, patient weight change was less than six percent. There was no correlation between CRP levels 


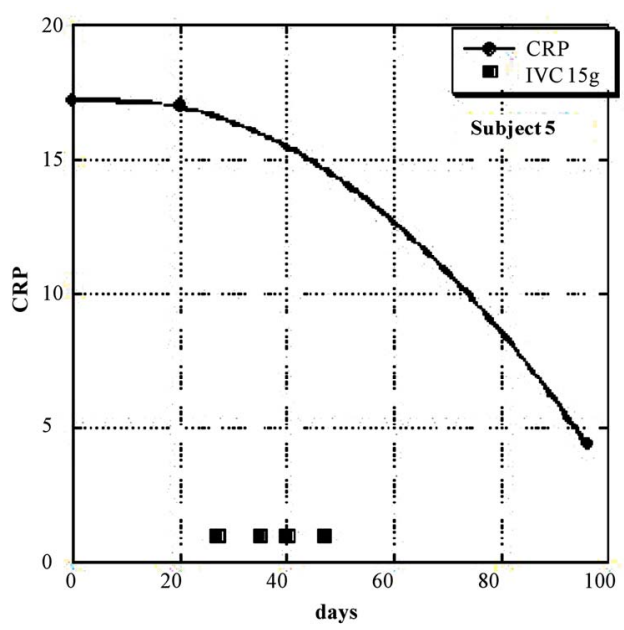

(a)

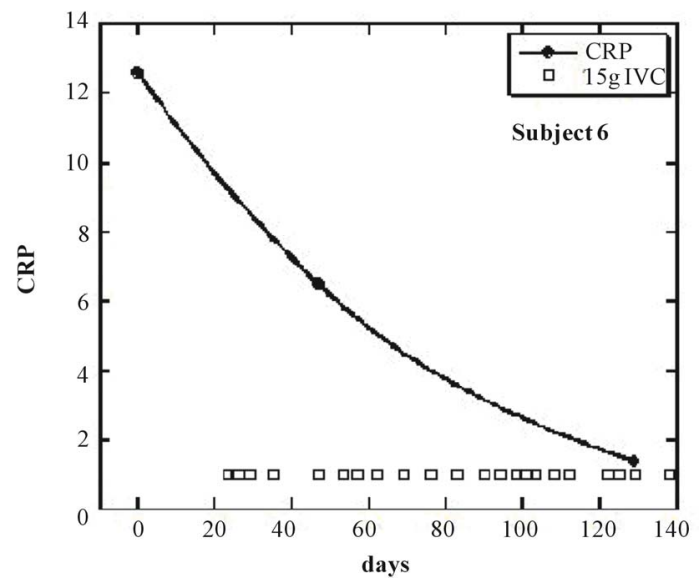

(b)

Figure 1. $(\mathrm{a}, \mathrm{b}) \mathrm{CRP}$ levels $(\mathrm{mg} / \mathrm{L})$ as a function of time for subjects 5 and 6 . IVC treatments of $15 \mathrm{~g}$ are indicated by boxes.

and weight changes.

\section{CONCLUSIONS}

Chronic inflammation underlies the pathology of rheumatoid arthritis. Decreasing inflammation and oxidative stress may provide protection for regenerating cartilage within the joint. Control of inflammation in patients with RA is also the important goal when it comes to the reduction of cardiovascular risk in these patients [63]. Our data, while preliminary in nature, suggest that IVC therapy may reduce inflammation as measured by C-reactive protein levels. The possible mechanism of this effect may be the suppression of NF- $\kappa \mathrm{B}$, which regulates the production of pro-inflammatory molecules (cyclooxygenase-2 matrix, metalloproteinase MMP-3, MMP-9, TNF$\alpha$, IL-1b, and other pro-inflammatory cytokines). The modulatory effects of high dose IVC may also be on the level of oxidative stress seen in these patients.

Based on this pilot study, we hypothesize that IVC ther apy be a useful strategy in treating RA, and that more

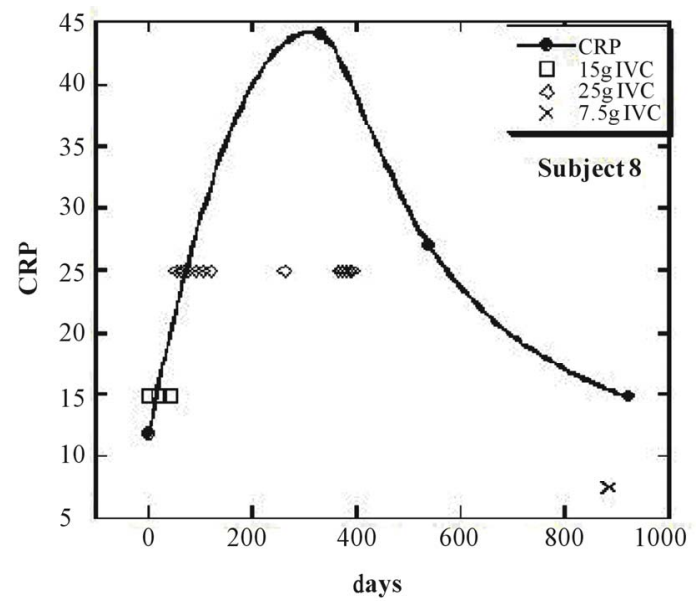

(a)

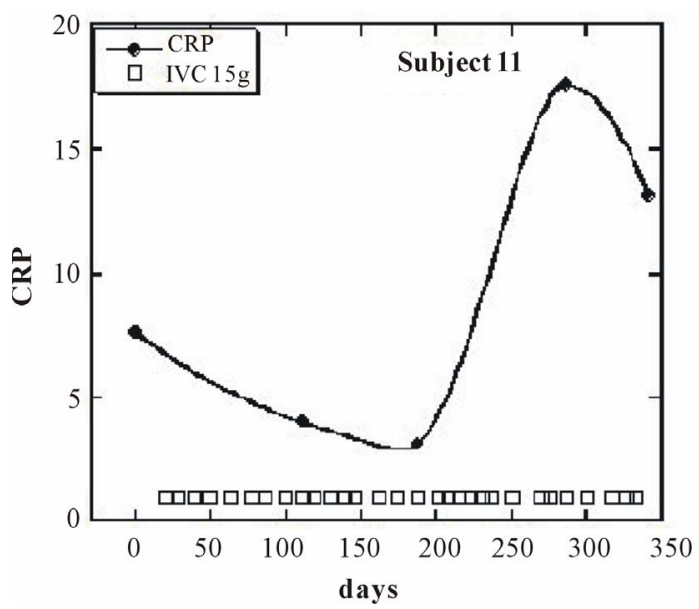

(b)

Figure 2. (a, b) CRP levels $(\mathrm{mg} / \mathrm{L})$ as a function of time (days) for subjects 8 and 11 . IVC treatments of $7.5 \mathrm{~g}, 15 \mathrm{~g}$, and $25 \mathrm{~g}$ are indicated by crosses, boxes, and diamonds, respectively.

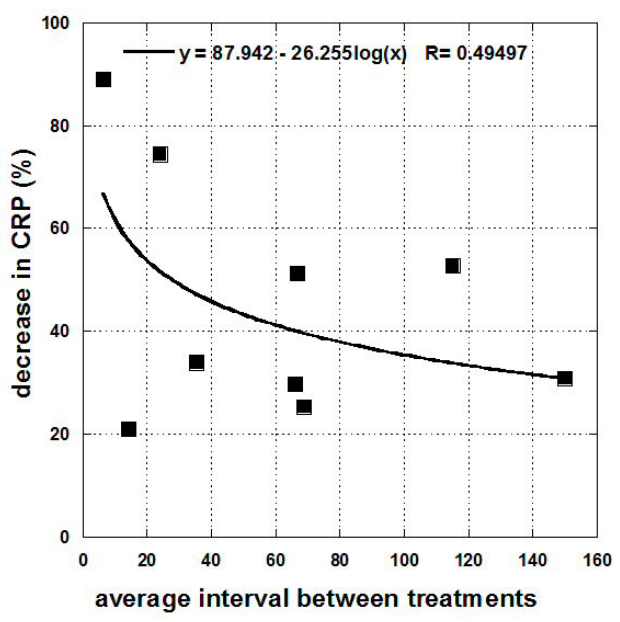

Figure 3. Drops in CRP level (mg/L) for the nine subjects who experienced decreases as a function of average frequency of the treatments (days of treatment divided by the number of treatments). 
research into this possibility is warranted. Future clinical studies should also include measurements of pro-inflammatory cytokine levels.

\section{ACKNOWLEDGEMENTS}

The authors acknowledge funding from A. P. Markin.

\section{REFERENCES}

[1] Tyler, J.A. (1985) Articular cartilage cultured with catabolin (pig interleukin 1) synthesizes a decreased number of normal proteoglycan molecules. Biochemical Journal, 227, 869-878.

[2] Gaby, A.R. (1999) Alternative treatments for rheumatoid arthritis. Alternative Medicine Review, 4.

[3] Pattison, D.J., Harrison, R.A. and Symmons, D.P. (2004) The role of diet in susceptibility to rheumatoid arthritis: A systematic review. The Journal of Rheumatology, 31, 1310-1319.

[4] Edmonds, S., Winyard, P., Guo, R., Kidd, B., Merry, P., Langrish-Smith, A., Hansen, C., Ramm, S. and Blake, D.R. (1997) Putative analgesic activity of repeated oral doses of vitamin $\mathrm{E}$ in the treatment of rheumatoid arthritis. Results of a prospective placebo controlled double blind trial. Annals of the Rheumatic Diseases, 56, 649-655. doi:10.1136/ard.56.11.649

[5] Peretz, A., Siderova, V. and Neve, J. (2001) Selenium supplementation in rheumatoid arthritis investigated in a double-blind, placebo-controlled trial. Scandinavian Journal of Rheumatology, 30, 208-212. doi:10.1080/030097401316909549

[6] Remans, P.H.J., Sont, J.K., Wagenaar, L.W., Wouterwesseling, W., Zuijderduin, W.M., Jongma, A., Breedveld, F.C. and van Laar, J.M. (2004) Nutrient supplementation with polyunsaturated fatty acids and micronutriens in rheumatoid arthritis: Clinical and biochemical effects. European Journal of Clinical Nutrition, 58, 839-845. doi:10.1038/sj.ejen.1601883

[7] Bae, S., Jung, W., Lee, E., Yu, R. and Sung, M. (2009) Effects of antioxidant supplements intervention on the level of plasma inflammatory molecules and disease severity of rheumatoid arthritis patients. Journal of the American College of Nutrition, 28, 56-62.

[8] Lipsky, P.E. (2000) Rheumatoid arthritis. In: Braunwald, E., Fauci, A.S., Kasper, D.L., Hauser, S.L., Longo, D.L. and Jameson, J.L., Eds., Harrison's Principles of Internal Medicine, McGraw Hill, New York, 1928-1936.

[9] Shingu, M., Nagai, Y., Isayama, T., Naono, T., Nobunaga, M. and Nagai, Y. (1993) The effects of cytokines on metalloproteinase inhibitors (TIMP) and collagenase production by human chondrocytes and TIMP production by synovial cells and endothelial cells. Clinical \& Experimental Immunology, 94, 145-149. doi:10.1111/j.1365-2249.1993.tb05992.x

[10] Feldmann, M., Brennan, F.M. and Maini, R.N. (1996) Role of cytokines in rheumatoid arthritis. Annual Review of Immunology, 14, 397-440. doi:10.1146/annurev.immunol.14.1.397

[11] Gowen, M., Wood, D.D., Ihrie, E.J., Meats, J.E. and Russell, R.G. (1984) Stimulation by human interleukin 1 of cartilage breakdown and production of collagenase and proteoglycanase by human chondrocytes but not by human osteoblasts in vitro. Biochimica et Biophysica Acta, 797, 186-193. doi:10.1016/0304-4165(84)90121-1

[12] Kevorkian, L., Young, D.A., Darrah, C., Donell, S.T., Shepstone, L., Porter, S., Brockappa Bank, S.M., Edwards, D.R., Parker, A.E. and Clark, I.M. (2004) Expression profiling of metalloproteinases and their inhibitors in cartilage. Arthritis \& Rheumatism, 50, 131-141. doi:10.1002/art.11433

[13] Martel-Pelletier, J. (1998) Pathophysiology of osteoarthritis. Osteoarthritis and Cartilage, 6, 374-376. doi:10.1053/joca.1998.0140

[14] Sarban, S., Kocyigit, A., Yazar, M. and Isikan, U.E. (2005) Plasma total antioxidant capacity, lipid peroxidation, and erythrocyte antioxidant enzyme activities in patients with rheumatoid arthritis and osteoarthritis. Clinical Biochemistry, 38, 981-986. doi:10.1016/j.clinbiochem.2005.08.003

[15] Kamanli, A., Naziroglu, M., Aydilek, N. and Hacievliyagil, C. (2004) Plasma lipid peroxidation and antioxidant levels in patients with rheumatoid arthritis. Cell Biochemistry and Function, 22, 53-57. doi:10.1002/cbf.1055

[16] Gambhir, J.K., Lali, P. and Jain, A.K. (1997) Correlation between blood antioxidant levels and lipid peroxidation in rheumatoid arthritis. Clinical Biochemistry, 30, 351-355. doi:10.1016/S0009-9120(96)00007-0

[17] Halliwell, B., Hoult, J.R. and Blake, D.R. (1988) Oxidants, inflammation, and anti-inflammatory drugs. FASEB Journal, 2, 2867-2873.

[18] Blake, D.R., Merry, P., Unsworth, J., Kidd, B.L., Outhwaite, J.M., Ballard, R., Morris, C.J., Gray, L. and Lunec J. (1989) Hypoxid-reperfusion injury in the inflamed human joint. The Lancet, 1, 289-293. doi:10.1016/S0140-6736(89)91305-6

[19] Bubici, C., Papa, S., Pham, C.G., Zazzeroni, F. and Franzoso G. (2006) The NF-kappa B-mediated control of ROS and JNK signaling. Histology and Histopathology, 21, 69-80.

[20] Siebenlist, U., Franzoso, G. and Brown, K. (1994) Structure, regulation and function of NF-kappa B. Annual Review of Cell Biology, 10, 405-455. doi:10.1146/annurev.cb.10.110194.002201

[21] Barnes, P.J. and Karin, M. (1997) Nuclear factor-kappa B: A pivotal transcription factor in chronic inflammatory diseases. The New England Journal of Medicine, 336, 1066-1071. doi:10.1056/NEJM199704103361506

[22] Kumar, A., Takada, Y., Boriek, A.M. and Aggarwal, B.B. (2004) Nuclear factor-kappa B: Its role in health and disease. Journal of Molecular Medicine, 82, 434-448. doi:10.1007/s00109-004-0555-y

[23] Simmonds, E. and Foxwell, B.M. (2008) Signaling, inflammation and arthritis NF-kappa B and its relevance to arthritis and inflammation. Rheumatology, 47, 584-590. 
[24] Fujisawa, K., Aono, H., Hasunuma, T., Yamamoto, K., Mita, S. and Nishioka, K. (1996) Activation of transcription factor NF-kappa B in human synovial cells in response to tumor necrosis factor alpha. Arthritis \& Rheumatism, 39, 197-203. doi:10.1002/art.1780390205

[25] Roshak, A.K., Jackson, J.R., McGough, K., Chabot-Fletcher, M., Mochan, E. and Marshall, L.A. (1996) Manipulation of distinct NF-kappa B proteins alters interleukin-1betainduced human rheumatoid synovial fibroblast prostaglandin $\mathrm{E}_{2}$ formation. The Journal of Biological Chemistry, 271, 31496-31501. doi:10.1074/jbc.271.49.31496

[26] Yamasaki, S., Kawakami, A., Nakashima, T., et al. (2001) Importance of NF-kappa B in rheumatoid synovial tissues: In situ NF-kappa B expression and in vitro study using cultured synovial cells. Annals of the Rheumatic Diseases, 60, 678-84. doi:10.1136/ard.60.7.678

[27] Carlsen, H., Moskaug, J.O., Fromm, S.H. and Blomhoff, R. (2002) In vivo imaging of NF-kappa B activity. The Journal of Immunology, 168, 1441-1446.

[28] Sioud, M., Mellbye, O. and Forre, O. (1998) Analysis of the NF-kappa B p65 subunit, Fas antigen, Fas ligand and Bcl-2-related proteins in the synovium of RA and polyarticular JRA. Clinical and Experimental Rheumatology, 16, 125-134

[29] Marok, R., Winyard, P.G., Coumbe, A. et al. (1996) Activation of the transcription factor nuclear factor-kappaB in human inflamed synovial tissue. Arthritis \& Rheumatism, 39, 583-591. doi:10.1002/art.1780390407

[30] Handel, M.L., McMorrow, L.B. and Gravallese, E.M. (1995) Nuclear factor-kappa B in rheumatoid synovium. Localization of p50 and p65. Arthritis \& Rheumatism, 38, 1762-1770. doi:10.1002/art.1780381209

[31] Benito, M.J., Murphy, E., Murphy, E.P., van den Berg, W.B., FitzGerald, O. and Bresnihan, B. (2004) Increased synovial tissue NF-kappa B1 expression at sites adjacent to the cartilage-pannus junction in rheumatoid arthritis. Arthritis \& Rheumatism, 50, 1781-1787. doi:10.1002/art.20260

[32] Danning, C.L., Illei, G.G., Hitchon, C., Greer, M.R., Boumpas, D.T. and McInnes, I.B. (2000) Macrophage- derived cytokine and nuclear factor kappa B p65 expression in synovial membrane and skin of patients with psoriatic arthritis. Arthritis \& Rheumatism. 43, 1244-1256. doi:10.1002/1529-0131(200006)43:6<1244::AID-ANR7> 3.0.CO;2-2

[33] Tsao, P.W., Suzuki, T., Totsuka, R., et al. (1997) The effect of dexamethasone on the expression of activated NF-kappa B in adjuvant arthritis. Clinical Immunology and Immunopathology, 83, 173-178. doi:10.1006/clin.1997.4333

[34] Han, Z., Boyle, D.L., Manning, A.M. and Firestein, G.S. (1998) AP-1 and NF-kappa B regulation in rheumatoid arthritis and murine collagen-induced arthritis. Autoimmunity, 28, 197-208. doi:10.3109/08916939808995367

[35] Wehling, N., Palmer, G.D., Pilapil, C., Liu, F., Wells, J.W., Müller, P.E., Evans, C.H. and Porter, R.M. (2009) Interleukin-1beta and tumor necrosis factor alpha inhibit chondrogenesis by human mesenchymal stem cells through
NF-kappa B-dependent pathways. Arthritis \& Rheumatism, 60, 801-812. doi:10.1002/art.24352

[36] Li, X.L. and Makarov, S.S. (2006) An essential role of $\mathrm{NF}-\kappa \mathrm{B}$ in the "tumor-like" phenotype of arthritic synoviocytes. Proceedings of the National Academy of Sciences, 103, 17432-17437. doi:10.1073/pnas.0607939103

[37] Yamasaki, S., Nakashima, T., Kawakami, A., Miyashita, T., Tanaka, F., Ida, H., Migita, K., Origuchi, T. and Eguchi, K. (2004) Cytokines regulate fibroblast-like synovial cell differentiation to adipocyte-like cells. Rheumatology, 43, 448-452.

[38] Zvaifler, N.J., Tsai, V., Alsalameh, S., von Kempis, J., Firestein, G.S. and Lotz, M. (1997) NF-KB activation provides the potential link between inflammation and hyperplasia in the arthritic joint. American Journal of Pathology, 150, 1125-1138. doi:10.1073/pnas.95.23.13859

[39] Miagkov, A.V., Kovalenko, D.V., Borwn, C.E., Didsbury, J.R., Cogswell, J.P., Stimpson, S.A., Baldin, A.S. and Makarov SS. (1998) NF-KB activation provides the potential link between inflammation and hyperplasia in the arthritic joint. Proceedings of the National Academy of Sciences of the USA, 95, 13859-13864.

[40] Bendich, A. and Langseth, L. (1995) The health effects of vitamin $\mathrm{C}$ supplementation: A review. Journal of the American College of Nutrition, 14, 124.

[41] Cathcart, R. F. (1984) Vitamin C in the treatment of acquired immune deficiency syndrome (AIDS). Medical Hypotheses, 14, 423. doi:10.1016/0306-9877(84)90149-X

[42] Mikirova, N.A., Ichim, T.E. and Riordan, N.H. (2008) Anti-angiogenic effect of high doses of ascorbic acid. Journal of Translational Medicine, $\mathbf{6}$.

[43] Duconge, J., Miranda-Massari, J.R., Gonzalez, M.J., Jackson, J.A., Warnock, W. and Riordan, N.H. (2008) Pharmacokinetics of vitamin C: Insights into the oral and intravenous administration of ascorbate. Puerto Rico Health Sciences Journal, 27, 7-19.

[44] Duconge, J., Miranda-Massari, J.R., González, M.J., Taylor, P.R., Riordan, H.D., Riordan, N.H., Casciari, J.J. and Alliston, K. (2007) Vitamin C pharmacokinetics after continuous infusion in a patient with prostate cancer. The Annals of Pharmacotherary, 41, 1082-1083. doi:10.1345/aph.1H654

[45] Riordan, H.D., Casciari, J.J., González, M.J., Riordan, N.H., Miranda-Massari, J.R., Taylor, P. and Jackson, J.A. (2005) A pilot clinical study of continuous intravenous ascorbate in terminal cancer patients. Puerto Rico Health Sciences Journal, 24, 269-276.

[46] Riordan HD et al (1990) Case study: High-dose intravenous Vitamin $\mathrm{C}$ in the treatment of a patient with adenocarcinoma of the kidney. Journal of Orthomolecular Medicine, 13.

[47] Ichim, T.E., Minev, B., Braciak, T., Luna, B., Hunninghake, R., Mikirova, N.A., Jackson, J.A., Gonzalez, M.J., Miranda-Massari, J.R., Alexandrescu, D.T., Dasanu, C., Bogin, V., Ancans, J., Stevens R.B., Markosian, B., Koropatnick, J., Chen, C.-S., and Riordan, N.H. (2011) Intravenous ascorbic acid to prevent and treat can- 
cer-associated sepsis? Journal of Translational Medicine, 9, 25. doi:10.1186/1479-5876-9-25

[48] Mikirova, N., Casciari, J., Rogers, A. and Taylor, P. (2012) Effect of high-dose intravenous vitamin C on inflammation in cancer patients. Journal of translational medicine, 10, 189. doi:10.1186/1479-5876-10-189

[49] Ford, E.S., Liu, S., Mannino, D.M., Giles, W.H. and Smith, S.J. (2003) C-reactive protein concentration and concentrations of blood vitamins, carotenoids, and selenium among United States adults. European Journal of Clinical Nutrition, 57, 1157-1163. doi:10.1038/sj.ejen.1601667

[50] Härtel, C., Strunk, T., Bucsky, P. and Schultz, C. (2004) Effects of vitamin $\mathrm{C}$ on intracytoplasmic cytokine production in human whole blood monocytes and lymphocytes. Cytokine, 27, 101-106. doi:10.1016/j.cyto.2004.02.004

[51] Caecamo, J.M., Borquez-Ojeda, O. and Golde, D.W. (2002) Vitamin $\mathrm{C}$ inhibites macrophage-colony-stimulating factor-induced signaling pathways. Blood, 99, 3205-3212. doi:10.1182/blood.V99.9.3205

[52] Bowie, A.G. and O’Neill, L.A.J. (2000) Vitamin C inhibits NF-kappa B activation by TNF via the activation of p38 mitogen-activated protein kinase1. The Journal of Immunology, 165, 7180-7188.

[53] Munoz, E., Blazquez, M.V., Ortiz, C., Gomez-Diaz, C. and Navas, P. (1997) Role of ascorbate in the activation of NF-kappa B by tumor necrosis factor-a in T-cells. Biochemical Journal, 325, 23.

[54] Harakeh, S., Jariwalla. R. J. (1997). NF-kappa B-independent suppression of HIV expression by ascorbic acid. AIDS Research and Human Retroviruses, 13, 235. doi:10.1089/aid.1997.13.235

[55] Bowie, A.G., Carcamo, J.M., Pedraza, A., Borquez-Qjeda, O. and Golde, D.W. (2002) Vitamin C suppresses TNFainduced $\mathrm{NF} \kappa \mathrm{B}$ activation by inhibiting $\mathrm{I} \kappa \mathrm{B} \alpha$ phosphorila- tion. Biochemistry, 41, 12995-13002. doi: $10.1021 / \mathrm{bi} 0263210$

[56] Halliwell, B. and Gutteridge, J.M. (1999) Free Radicals in Biology and Medicine, Oxford University Press, New York.

[57] Calder, P.C., Albers, R., Antoine, J.M., et al. (2009) Inflammatory disease processes and interactions with nutrition. British Journal of Nutrition, 101, S1-S45.

[58] Boyera, N., Galey, I. and Bernard, B.A. (1998) Effect of vitamin $\mathrm{C}$ and its derivatives on collagen synthesis and cross-linking by normal human fibroblasts. International Journal of Cosmetic Science, 20, 151-158.

[59] Franceschi, R.T., Iyer, B.S. and Cui, Y.L. (1994) Effects of ascorbic acid on collagen matrix formation and osteoblast differentiation in murine MC3T3-E1 cells. Journal of Bone and Mineral Research, 9, 843-854.

[60] Abrams E, Sandsont J. (1964) Effect of ascorbic acid on rheumatoid synovial fluid. Annals of the Rheumatic Diseases, 23, 295. doi:10.1161/01.CIR.0000125690.80303.A8

[61] Riordan, H.D., Casciari, J.J., González, M.J., Riordan, N.H., Miranda-Massari, J.R., Taylor, P. and Jackson, J.A. (2005) A pilot clinical study of continuous intravenous ascorbate in terminal cancer patients. Puerto Rico Health Sciences Journal, 24, 269-276.

[62] Ridker, P.M. and Cook, N. (2004) Clinical usefulness of very high and very low levels of C-reactive protein across the full range of Framingham Risk Scores. Circulation, 109, 1955-1959.

[63] Goodson, N.J., Symmons, D.P., Scott, D.G., Bunn, D., Lunt, M. and Silman, A.J. (2005) Baseline levels of C-reactive protein and prediction of death from cardiovascular disease in patients with inflammatory polyarthritis: A ten-year follow up study of a primary care-based inception cohort. Arthritis \& Rheumatism, 52, 2293-2299. doi:10.1002/art.21204 